\title{
Development of Webtoon non-test instrument as education media
}

\author{
Mery Berlian', Rian Vebrianto ${ }^{2}$, Musa Thahir $^{3}$ \\ ${ }^{1}$ Department of Agribusiness, Faculty of Mathematics and Natural Sciences, Universitas Terbuka, Indonesia \\ ${ }^{2}$ Department of Master Education for Madrasah Ibtidaiyah Teachers, Faculty of Education and Teacher Training, \\ Universitas Islam Negeri Sultan Syarif Kasim Riau, Indonesia \\ ${ }^{3}$ Department of Mathematic Education, Faculty of Education and Teacher Training, Universitas Islam Negeri Sultan \\ Syarif Kasim Riau, Indonesia
}

\begin{tabular}{l} 
Article Info \\
\hline Article history: \\
Received Sep 8, 2020 \\
Revised Jan 2, 2020 \\
Accepted Feb 5, 2021 \\
\hline
\end{tabular}

\section{Keywords:}

Development

Education media

Interest

Motivation

Non-test instrument

Webtoon

\section{Corresponding Author:}

Rian Vebrianto

Department of Master Education for Madrasah Ibtidaiyah Teachers

Faculty of Education and Teacher Training

Universitas Islam Negeri Sultan Syarif Kasim Riau

Jl. Subrantas Km. 15, Pekanbaru, 28293 Indonesia

Email: rian.vebrianto@uin-suska.ac.id

\begin{abstract}
The objective of this research was to develop non-test instrument or questionnaire to measure the evaluation of the use of Webtoon among the students of Open University in Pekanbaru, Riau, Indonesia and to obtain the instrument's validity and reliability. This research employed the Analysis, Design, Development, Implementation, Evaluation (ADDIE) instructional model. The data were collected using online questionnaire. There were 55 respondents participated in this research. The data collected were analyzed descriptively using SPSS program version 23.00 for windows. The result of the data analysis indicated that the instrument has the percentage of agreement result of $82.75 \%$ (valid) and Cronbach alpha with score 0.942 (reliable). The data proved that the instrument has very feasible. This result showed that this research and development produced Webtoon non-test instrument which is valid and reliable.
\end{abstract}

This is an open access article under the CC BY-SA license.

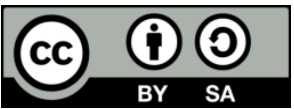

\section{INTRODUCTION}

Science and technology development increases as time goes by and affect the communication technology significantly. This is indicated by the sophistication in the current mass communication media such as radio, television, telephone and internet as the most current one [1]. Internet becomes one of the modern communication media interested by many people since it is easily accessed [2]. There are 3.6 billion internet user throughout the world in 2018 and according to Indonesia internet service association (APJII), more than $50 \%$ or about 143 million Indonesian have connected to the internet [3]. LINE Webtoon is released in 2004 in South Korea by Naver and officially released in April 2015 in Indonesia [4]. Since its release, LINE Webtoon has been obtaining positive response from many people. The active users of LINE Webtoon in Indonesia reached 6 million people which are the highest active user of LINE Webtoon compared to other countries [5-7]. The presence of internet makes individual to become easier in accessing all information, whether it is news, music, entertainment, new trend and others from various parts of the world without any limit of space and time. 
One of the effects of technology development is the learning media. Learning media is the source of learning for university students. It means that the media contains material that must be learned by the students whether it is individually or in group [8-10]. Therefore, it can be considered that media has utilization to explain message, overcome the limitation of space, time, personnel and sensory, emerge learning motivation and interaction between the students and media so that it enables the students to learn independently according to their ability as well as visual, auditory and kinesthetic skills. Learning process can occur anywhere and anytime based on what encountered by the individual in his daily life [11-13]. Learning process can last throughout life because learning process do not know time and place. In addition to experiencing formal learning in classroom, students also have responsibility to learn independently. Independent learning carried out by students according to the procedure and media they preferred [14-16]. Based on the above explanation, then this research should develop interesting media to attract the students in learning macromolecular chemistry, overcoming space and time limitation, clarifying the message and emerging students' learning motivation so that the students can learn independently through line Webtoon.

Webtoon is digital comic which is easily accessed through smartphone or computer/laptop since almost all students have smartphone or computer/laptop [17]. Webtoon is the acronym from website cartoon, in which the extensive meaning of Webtoon is a collection of images published online [18]. Webtoon is also called as sub-genre of manhwa but published differently, in which manhwa is published physically in magazine or book, while Webtoon is published through internet media, usually in comic hosting sites [19]. Line Webtoon has advantages in learning, one of them is as good educational media to improve the students interest in learning and its easily-accessed anywhere [20]. In addition, Webtoon also has potential to increase the self-motivation in facing scientific issue [21]. Based on a previous research project conducted, it obtained that the users of Webtoon service were satisfied if they obtained the information they desired, not only concerning the interesting matters but also important matters [22]. This means that learning media in the form of Webtoon is used because Webtoon readers do not only obtain interesting things, but also obtained interesting things in the form of learning material. Furthermore, other research obtained the virtue of scientific comic which is its benefits for the learners to obtain fair achievement in cognitive aspect [23]. Comic can improve the mathematical knowledge of dyslexic students [24]. Thus, there is need emerges in the form of developing instruments in this field.

In the Law of the Republic of Indonesia Number 14 of 2005 concerning Teachers and Lecturers, article 20 states that in carrying out professional duties, teachers and lecturers are obliged to plan to learn, carry out a quality learning process, and assess and evaluate learning outcomes. The evaluation process is one of the teacher's duties that will determine the next learning process's direction. Evaluation can be stated as a systematic process in assessing the level of achievement of instructional goals [25]. Meanwhile, another opinion states that evaluation is a systematic process for determining value based on data collected through measurement [26]. The value-taking process must be carried out objectively, and it should be taken care of that subjective elements are not included as a consideration and assessment. In other words, it can be stated that evaluation consists of the two steps ahead, namely measuring and assessing. The review is a systematic and continuous process or activity to collect information about the learning process and outcomes of students to make decisions based on specific criteria and considerations [27, 28].

The purpose of the assessment is to find out how far the teacher has succeeded in carrying out the learning process, which is used for feedback for the teacher in planning the next learning process [29, 30]. Often in the learning process, aspects of the evaluation of learning outcomes are ignored [31]. Because the teacher focuses too much on what will be taught to students; as a result, the learning process runs nicely and neatly, but the assessment tools used no longer see the target to be assessed. Improving the quality of education is inseparable from the application of assessments that can accurately measure the result of a learning process, meaning that to determine the result in learning, a quality measuring instrument is needed $[32,33]$. The teacher's ability to arrange test instruments positively affects student learning outcomes. With an assessment test instrument that meets the criteria, of course, student learning outcomes will be adequately detected and can be used as evaluation material for other learning programs. A test is said to be good if it has criteria, including validity, reliability, and has practical value [34, 35].

The lecturers' ability to make assessment instruments did not meet the criteria for fair test assessment. Researchers have made preliminary observations on August 25, 2020, at the Open University by collecting test kits which include: 1) Data shows that a total of 30 questions (75\%) are invalid and only ten questions $(25 \%)$ are valid; 2) The reliability of the items was 0.46 , which means that it was in a suitable category; 3 ) There are $42.5 \%$ of the items in the easy class, $40 \%$ of the items in the medium category, and $17.5 \%$ of the items in the challenging course; and 4) The difference is that $7.5 \%$ is terrible, $45 \%$ is awful, $13 \%$ is sufficient, $15 \%$ is good, and none is in an outstanding category. From these data, it can be concluded that the knowledge instrument has not met the type of a good test instrument because there are still invalid questions, the reliability is still in the excellent category, the difficulty level of the items always does not 
meet the standard, many of them are categorized as bad and some even very bad. Meanwhile, based on the results of interviews with one of the tutors on August 20, 2020, at the Open University, the results were: 1) The lecturers were only limited to making assessment instruments, the level of validity, reliability, difficulty level and distribution had never been analyzed the realm of knowledge; 2) Lecturers do not understand how to interpret assessment instruments; 3) Lecturers do not understand the category of right assessment instruments; 4) The assessment instruments used this year is the same as the assessment instruments used last year meaning the tools are not evaluated.

Based on the data from the above analysis, it can be concluded that it is necessary to develop an assessment instrument used for non-test tools or questionnaires to measure the evaluation of the use of online comics among students at UPBJJ Pekanbaru Open University that meet the criteria of right assessment instruments, namely validity and reliability.

\section{RESEARCH METHOD}

This research and development was designed to produce Webtoon non-test instrument. The development model of Webtoon non-test instrument adapted to the development model stated by Lee and Owens, which is ADDIE instructional model [36]. The stages of development include analysis, design, development, implementation, and evaluation. The respondents of this research were 55 samples with random sampling process from university students and community. Validation was done to determine whether the instrument developed was valid or not. The validation result was in the form of suggestion from the validator and validity percentage of Webtoon non-test instrument. Validation of instrument usually we get through the percentage of expert agreement. The construct of Webtoon non-test instrument includes: 1) didactic component, 2) Webtoon comic construction, 3) Webtoon comic technique, 4) easiness in the using, 5) efficiency of Webtoon comic, 6) benefits, 7) interest and 8) motivation. The validity percentage of Webtoon non-test instrument was obtained from the mean score of questionnaire using validation questionnaire of Likert scale from expert agreement. Likert scale used is in the form of number 4, 3, 2 and 1. The criteria of each Likert scales is presented in Table 1 [37].

Table 1. Modification of Likert scale evaluation criteria

\begin{tabular}{cc}
\hline Score & Explanation \\
\hline 4 & Scale 4, if the user gives strongly agree evaluation \\
3 & Scale 3, if the user gives agree evaluation \\
2 & Scale 2, if the user gives disagree evaluation \\
1 & Scale 1, if the user gives strongly disagree evaluation \\
\hline
\end{tabular}

The analysis of validation result data by the user is formulated in (1)

$$
P \quad=\frac{\sum x}{\sum x_{i}} \times 100 \%
$$

Explanation:

$\mathrm{P} \quad=$ score percentage

$\sum x=$ number of total score from the user in one question item

$\sum x_{i}=$ maximum score of one question item

Based on the analysis result, it was known the validity of the instrument developed. The instrument of evaluation was considered feasible if the interpretation $\geq 61 \%$. The criteria of evaluation instrument score interpretation is presented in Table 2 [37].

Table 2. Criteria of instrument feasibility score

\begin{tabular}{cc}
\hline Percentage & Criteria \\
\hline $0-20 \%$ & Not feasible \\
$21 \%-40 \%$ & Less feasible \\
$41 \%-60 \%$ & Quite feasible \\
$61 \%-80 \%$ & Feasible \\
$81 \%-100 \%$ & Strongly feasible \\
\hline
\end{tabular}


The validity of question item was obtained from empirical respondents of this research based on the criteria of evaluation instrument score interpretation. The researcher determine reliability of instrument based on the data obtained in which the Question item in an instrument is considered as valid if the count Pearson coefficient (r-count) is higher than the Pearson coefficient of the table (r-table) [38]. Furthermore, the validity of an instrument must have minimum score of 0.3 [39] and reliability score of the instrument must be at the range of $0.6<X<1$ [40]. The interpretation of test correlation number overall can be seen in Table 3 [37].

Table 3. Interpretation of non-test correlation number

\begin{tabular}{lc}
\hline Correlation number & Criteria \\
\hline $0.800<\mathrm{r}_{11} \leq 1.000$ & Very high \\
$0.600<\mathrm{r}_{11} \leq 0.800$ & High \\
$0.400<\mathrm{r}_{11} \leq 0.600$ & Fair \\
$0.200<\mathrm{r}_{11} \leq 0.400$ & Low \\
$0.000<\mathrm{r}_{11} \leq 0.200$ & Vary low \\
\hline
\end{tabular}

\section{RESULTS AND DISCUSSION}

\subsection{Instrument validation result}

The validation result of the non-test instrument in the forms of evaluation and suggestion from the user used online questionnaire. The validation sheet included feasibility in the aspects of didactic component, Webtoon comic construction, Webtoon comic technique, easiness in the using, efficiency of Webtoon comic, benefits, interest, and motivation. The score obtained from the user was converted into percentage to know the instrument validity level. The data were collected using online questionnaire both students and community with the random sampling were 55 respondents in this research. The data collected were analyzed descriptively using SPSS program version 23.00 for Windows. The validation result of each component is presented in Table 4.

Table 4. Validation result of Webtoon non test instrument

\begin{tabular}{cccc}
\hline Aspect evaluated & $\mathrm{n}$ & Percentage & Criteria \\
\hline Didactic component & 55 & $80.27 \%$ & Valid \\
Webtoon comic construction & 55 & $83.64 \%$ & Strongly valid \\
Comic technique & 55 & $84.00 \%$ & Strongly valid \\
Easiness in the using & 55 & $81.36 \%$ & Strongly valid \\
Efficiency of Webtoon comic & 55 & $84.82 \%$ & Strongly valid \\
Benefits & 55 & $83.45 \%$ & Strongly valid \\
Interest & 55 & $82.87 \%$ & Strongly valid \\
Motivation & 55 & $81.57 \%$ & Strongly valid \\
\hline
\end{tabular}

Table 4 explains that from the non-test instrument developed that the construct (didactic component, Webtoon comic construction, Webtoon comic technique, easiness in the using, efficiency of Webtoon comic, benefits, interest, and motivation) had strongly valid criteria. This is due to the mean of percentage score is at the range of $81 \%-100 \%$ with the category if strongly valid. Based on the data that the instrument has valid criteria. This result is supported by the previous research projects which produced feasible instrument to be used [41, 42]. Feasibility test is also very important to be done as stated by Widyaningsih that feasibility evaluation is very important to ensure the feasibility of learning material to be used in learning process $[43,44]$. Through validation test and instrument feasibility, development result is considered as feasible by the users to be used in evaluating the line Webtoon as educational media.

\subsection{Result of empirical try-out test of the instrument}

The empirical try-out test of the Webtoon non-test instrument was done on the students of Open University consisting of various study programs. The subjects of respondents of this research were 55 respondents. The try-out of this non-test instrument aimed to know the reliability of the questions raised. The summary of the validation result of the questions item of the Webtoon non-test instrument that has been developed is presented in Table 5 . 
Table 5. Instrument validity using item correlation score of corrected item-total correlation for each study construct

\begin{tabular}{ccc}
\hline Construct & Correlation score of corrected item-total correlation & Criteria \\
\hline Didactic component & 0.739 & Valid \\
Webtoon comic construction & 0.738 & Valid \\
Webtoon comic technique & 0.715 & Valid \\
Easiness in the using & 0.735 & Valid \\
Efficiency of Webtoon comic & 0.861 & Valid \\
Benefits & 0.888 & Valid \\
Interest & 0.873 & Valid \\
Motivation & 0.788 & Valid \\
\hline
\end{tabular}

Table 5 shows that the r-table score is more than 0.254 obtained from the table with a degree of freedom (df) of 53 from 34 questionnaires distributed as trials. In addition, the correlation between the items with score of more than 0.25 is considered as a high score based on Table 3 [39]. From the whole calculation, all items were declared valid because the score of $r$-count $>r$-table so that all question items can be used to measure the evaluation of the use of online comics for students. The question item in an instrument is considered to be valid if the calculated Pearson coefficient score (r-count) is higher than the Pearson table coefficient score (r-table) [45, 46]. Furthermore, 34 item questions which are valid are calculated regarding its reliability. The result of reliability calculation of the question item obtained 0.942 with the criteria of very high as presented in Table 6.

Table 6. Index of Cronbach alpha reliability of each study construct

\begin{tabular}{ccc}
\hline Construct & Overall Cronbach alpha score & Criteria \\
\hline Didactic component & .938 & Very High \\
Webtoon comic construction & .938 & Very High \\
Webtoon comic technique & .939 & Very High \\
Easiness in the using & .937 & Very High \\
Efficiency of Webtoon comic & .929 & Very High \\
Benefits & .927 & Very High \\
Interest & .928 & Very High \\
Motivation & .934 & Very High \\
\hline
\end{tabular}

Table 6 shows that Cronbach alpha Reliability Index score obtained for each study construct in this research for didactic component, Webtoon comic construction, Webtoon comic technique, easiness in the using, efficiency of Webtoon comic, benefits, interest, and motivation respectively are 0.938, 0.938, 0.939, $0.937,0.929,0.927,0.928$, and 0.934 . This indicates that the reliability score $>0.60$ for each study construct. This result is supported by the statement given by Basuki and Haryanto that instrument has high correlation and reliable at the range of $0.6<X<1[47,48]$. Thus, the eight study constructs have met the reliability requirement so that it can be used for further research use. Table 5 which Instrument Validity Using Item Correlation Score of Corrected Item-Total Correlation For each study construct are valid (score is more than 0.25 obtained) and Table 6 present information the instrument which Cronbach alpha Reliability Index score more than 0.6 obtained are reliable. so that Webtoon non-test instrument has met the empirical try-out, are valid and reliabel criteria. This result is supported by the opinion that an assessment instrument that can be used is an instrument that has met the valid criteria [49-51], the instrument also must met high validity requirement $[52,53]$. The results of this study are also supported by the findings of the research carried out by Inteni, et al., who stated that one of the conditions for an instrument that is suitable for use in research is valid [54, 55]. In addition to valid, instrument must also met reliability criteria, in which having Cronbach alpha score of more than 0.6 [56] if the Cronbach alpha reliability coefficient is at teh range of $0.70-0.90$ [57]. The results of this study are also supported by the opinion given by Tang Keow, et al. that the scale and criteria used to measure the test instrument must meet very reliable criteria [58].

Thus, the research instrument that measures the evaluation of the use of line Webtoon that has been tested was deemed worthy of use and was trusted to be used in research that measures evaluation of the use of the line Webtoon for users. This is supported by previous research which stated that the instruments used were derived from the selection of valid and reliable tools [59-61]. The evaluation instrument for the use of the Webtoon line for users can prevent speculation from users in making evaluation, especially in determining the final score after carrying out research on the achievement of evaluating the use of the Webtoon for users. 


\section{CONCLUSION}

This research and development resulted in a product in the form of a Webtoon non-test instrument. The non-test instrument developed is an online questionnaire using a Likert scale. The results of data analysis from the validation results show that the instrument developed is very feasible. This is indicated by the average percentage of validation results of $82.75 \%$ with a very valid category. Based on the results of the empirical test analysis obtained 34 valid questions with an average correlation score of 0.792 with valid criteria and a very high level of reliability of 0.942 . These results indicate that in this research and development, a valid and reliable non-test Webtoon instrument has been succesfully produced. Users are expected to be able to use non-test instruments that have been developed to measure the use of Webtoons to train and develop students' abilities in using Webtoon. Furthermore, it is necessary to test the Webtoon nontest instrument on a broader scale so that the effectiveness of the Webtoon non-test instrument being developed can be seen.

\section{ACKNOWLEDGEMENTS}

This research was conducted well and systematically because of the appropriate information and financial support by the head of Open University in Pekanbaru, Riau, Indonesia.

\section{REFERENCES}

[1] M. Ngafifi, "Advances in technology and patterns of human life in socio-cultural perspective," J. Pembang. Pendidik. Fondasi dan Apl., vol. 2, no. 1, pp. 33-47, 2014, doi: 10.21831/jppfa.v2i1.2616.

[2] M. C. B. Umanailo, et al., "Cybercrime case as impact development of communication technology that troubling society," Int. J. Sci. Technol. Res., vol. 8, no. 9, pp. 1224-1228, 2019, doi: 10.5281/zenodo.3457420.

[3] D. J. Riveong and S. H. Rachmad, "Internet Users, Market Target and Digital Trading of MSMEs in Indonesia Internet Users, Market Target and Digital Trading of MSMEs in Indonesia," in IARIW General Conference, 2018, pp. 1-12.

[4] B. Yecies, A. Shim, and J. Yang, 13 Chinese Transcreators, Webtoons and the Korean Digital Wave. Digital Transactions in Asia: Economic, Informational, and Social Exchanges, 2019.

[5] D. Susilo, N. Christantyawati, I. Joko Prasetyo, and S. Rodrick Juraman, "Content Analysis of LINE Application User: Intersecting Technology and Social Needed,” J. Phys. Conf. Ser., vol. 1175, no. 1, pp. 1-6, 2019, doi: 10.1088/1742-6596/1175/1/012224.

[6] J. Y. Pyo, M. Jang, and T. J. Yoon, "Dynamics Between Agents in The New Webtoon Ecosystem in Korea: Responses to Waves of Transmedia and Transnationalism," Int. J. Commun., vol. 13, pp. 2161-2178, 2019.

[7] Z. E. Subandi and T. P. Sadono, "Commodification, Spatialization, and Structuring in New Media in Indonesia (Vincent Mosco's Political Economy of Communication on the Webtoon Line) (in Bahasa)," in National Conference of Creative Industry, 2018, pp. 821-842, doi: 10.30813/ncci.v0i0.1297.

[8] Maimunah, "Methods of Using Learning Media (in Bahasa)," Al-Afkar J. Keislam. Perad., vol. 5, no. 1, pp. 1-24, 2016, doi: 10.28944/afkar.v5i1.107.

[9] Z. Mustika, "Media urgency in supporting a conducive learning process (in Bahasa)," CIRCUIT J. Ilm. Pendidik. Tek. Elektro, vol. 1, no. 1, pp. 60-73, 2015, doi: 10.22373/crc.v1i1.311.

[10] D. Erfianto, W. P. Rahayu, and D. D. Kusumajanto, "Application of Blog For Media Learning of Online Marketing courses (in Bahasa),” J. Pendidik. Bisnis dan Manaj., vol. 1, no. 1, pp. 1-70, 2015.

[11] A. C. Hayk and U. Sailer, "Cosmopolitan Encounters Provoke A Change in Habits: How Chinese Slot Machines Affect Rural Life in Ghana," Geoforum, vol. 111, pp. 39-47, 2020, doi: 10.1016/j.geoforum.2020.03.005.

[12] F. Eliza, D. E. Myori, and R. Fadli, "Validity of Android-Based Learning Media in Subject Measurement and Instrumentation,” J. Phys. Conf. Ser., vol. 1387, no. 1, pp. 1-7, 2019, doi: 10.1088/1742-6596/1387/1/012028.

[13] I. M. Negara, "Phenomenological study: The integration of technology as media in teaching and learning process based on students' perception," Spectr. J. Ilm. STBA, vol. 5, no. 2, pp. 014-030, 2019. [Online]. Available: http://journal.stbapontianak.ac.id/index.php/vol12/article/view/39/39.

[14] J. Abbas, J. Aman, M. Nurunnabi, and S. Bano, "The Impact of Social Media on Learning Behavior for Sustainable Education: Evidence of Students from Selected Universities in Pakistan,” Sustainability, vol. 11, no. 6, pp. 1-23, 2019, doi: 10.3390/su11061683.

[15] N. Ibrahim, "The relationship between independent learning and achievement motivation with Islamic religious education learning outcomes Terbuka Junior High School (in Bahasa)," Lentera Pendidik., vol. 15, no. 1, pp. 1-17, 2012.

[16] M. Dewi, Y. R. Sari, S. Amna, Rasmita, and R. Susanti, "The understanding of Lecturers About The New Literacy in Industrial Revolution Era 4.0: A Study Case of University of Putra Indonesia YPTK Padang," J. Phys. Conf. Ser., vol. 1339, no. 1, pp. 1-7, 2019, doi: 10.1088/1742-6596/1339/1/012105.

[17] U. Sumanjaya and R. T. Padmaningrum, "Develompment of chemistry Webtoon for learning of macromolecule material (in Bahasa)," J. Pembelajaran Kim., vol. 7, no. 5, pp. 210-219, 2018.

[18] J. H. Kim and J. Yu, "Platformizing Webtoons: The Impact on Creative and Digital Labor in South Korea," Soc. Media Soc., vol. 5, no. 4, pp. 1-11, 2019, doi: 10.1177/2056305119880174. 
[19] D. B. Harmoko and M. S. Sumbawati, "Mobile Webtoon Development in Game Programming Courses at Universitas Negeri Surabaya (in Bahasa)," IT-EDU, vol. 2, no. 1, pp. 102-109, 2017.

[20] R. K. Jati, "The design of Webtoon comic media about historical lesson (IPS) of 5th grade elementary school in Jogja (in Bahasa)," in e-Proceeding of Art \& Design, 2017, vol. 4, no. 3, pp. 685-694.

[21] F. Affeldt, D. Meinhart, and I. Eilks, "The Use of Comics in Experimental Instructions in a Non-formal Chemistry Learning Context," Int. J. Educ. Math. Sci. Technol., vol. 6, no. 1, pp. 93-104, 2018, doi: 10.18404/ijemst.380620.

[22] M.-B. Kim, S.-H. Lee, B.-J. Kwon, and G. Gim, "A Study of the Effects of Webtoon Contents and Cooperative Characteristics on Open Collaboration Platform Usage," Int. J. Softw. Eng. its Appl., vol. 10, no. 9, pp. 51-64, 2016, doi: 10.14257/ijseia.2016.10.9.06.

[23] S.-F. Lin and H. Lin, "Learning nanotechnology with texts and comics: the impacts on students of different achievement levels," Int. J. Sci. Educ., vol. 38, no. 8, pp. 1373-1391, 2016, doi: 10.1080/09500693.2016.1191089.

[24] T. L. Toh, L. P. Cheng, S. Y. Ho, H. Jiang, and K. M. Lim, "Use of comics to enhance students' learning for the development of the twenty-first century competencies in the mathematics classroom," Asia Pacific J. Educ., vol. 37, no. 4, pp. 437-452, 2017, doi: 10.1080/02188791.2017.1339344.

[25] V. T. K. Anh, "Evaluation Models in Educational Program: Strengths and Weaknesses," VNU J. Foreign Stud., vol. 34, no. 2, pp. 140-149, 2018, doi: 10.25073/2525-2445/vnufs.4252.

[26] M. Unterkalmsteiner, T. Gorschek, A. K. M. M. Islam, C. K. Cheng, R. B. Permadi, and R. Feldt, "Evaluation and Measurement of Software Process Improvement-A Systematic Literature review," IEEE Trans. Softw. Eng., vol. 38, no. 2, pp. 398-424, 2012, doi: 10.1109/TSE.2011.26.

[27] C. D. Hundhausen, D. M. Olivares, and A. S. Carter, "IDE-Based Learning Analytics for Computing Education: A Process Model, Critical Review, and Research Agenda," ACM Trans. Comput. Educ., vol. 17, no. 3, pp. 1-26, 2017, doi: 10.1145/3105759.

[28] J. A. Muskin, "Student Learning Assessment and The Curriculum: Issues and Implications For Policy, Design and Implementation," Curr. Crit. Issues Curric. Learn., vol. 1, no. 1, pp. 1-29, 2015.

[29] I. Tosuncuoglu, "Importance of Assessment in ELT," J. Educ. Train. Stud., vol. 6, no. 9, pp. 163-167, 2018, doi: 10.11114/jets.v6i9.3443.

[30] A. Azis, "Teachers' conceptions and use of assessment in student learning," Indones. J. Appl. Linguist., vol. 2, no. 1, pp. 40-51, 2012, doi: 10.17509/ijal.v2i1.72.

[31] U. Faizah, "Performance evaluation of educators and educational staff and Islamic education learning process in Indonesia (in Bahasa)," Al-Fikri J. Stud. dan Penelit. Pendidik. Islam, vol. 2, no. 2, pp. 44-54, 2019.

[32] H. Y. Suhendi, M. A. Ramdhani, and F. S. Irwansyah, "Verification Concept of Assesment for Physics Education Student Learning Outcome," Int. J. Eng. Technol., vol. 7, no. 3.21, pp. 321-325, 2018, doi: 10.14419/ijet.v7i3.21.17181.

[33] D. Darmawan, D. Yatimah, K. Sasmita, and R. Syah, "Analysis of Non-Formal Education Tutor Capabilities in Exploring Assessment for Science Learning," J. Pendidik. IPA Indones., vol. 9, no. 2, pp. 267-275, 2020, doi: 10.15294/jpii.v9i2.24025.

[34] E. R. Ardyanto, M. Winarno, and S. Adi, "The Development of Knowledge Instruments for PJOK subject for XII grade High School students (in Bahasa)," J. Pendidik. - Teor. Penelitian, dan Pengemb., vol. 1, no. 10, pp. 1897-1903, 2016.

[35] Z. Arifin, "Instrument Criteria in a Research (in Bahasa)," J. Theorems (the Orig. Res. Math), vol. 2, no. 1, pp. $28-36,2017$

[36] W. Lee and D. Owens, Multimedia-Based Instructional Design. San Francisco: Pleiffer, 2004.

[37] S. K. E. Novanti, E. Yulianti, and V. R. Mustikasari, "Development of Science Literacy Test Instruments for Junior High School Students on Substance Pressure and Its Application in Daily Life (in Bahasa)," J. Pembelajaran Sains, vol. 2, no. 2, pp. 6-12, 2018.

[38] D. Triana and W. O. Oktavianto, "Relevance of Civil Engineering Contractor Qualifications to Quality of Construction Project Work in Banten Province (in Bahasa)," J. Fondasi, vol. 1, no. 1, pp. 182-190, 2013.

[39] J. Nunnally, The Study of Change in Evaluation Research: Principal Concerning Measurement, Experimental Design and Analysis. Beverly Hills: Sage Publication, 1978.

[40] J. Joseph F. Hair, W. C. Black, B. J. Babin, and R. E. Anderson, Multivariate Data Analysis. New Jersey: Pearson Educational International, 2006.

[41] H. Akhsan, et al., "Development of Higher-Order Thinking Test Instrument on Fluid Material for Senior High School Students," J. Phys. Conf. Ser., vol. 1467, no. 1, pp. 1-6, 2020, doi: 10.1088/1742-6596/1467/1/012046.

[42] Nasrah, Jasruddin, and M. Tawil, "Development of Physics Learning Tools Based on Contexstual Teaching And Learning (CTL) Approach to Motivate and Improve Physics Learning Outcomes for 2nd grade of SMP Negeri 1 Balocci Pangkep (in Bahasa)," J. Pendidik. Fis., vol. 5, no. 2, pp. 235-248, 2015.

[43] D. I. Sistyarini and S. D. Nurtjahyani, "Analysis of The Validity of the Development of Problem Based Handout onEnvironmental Content Chapters Class VII SMP/MTS (in Bahasa)," Proceeding Biol. Educ. Conf., vol. 14, no. 1, pp. 581-584, 2017. [Online]. Available: https://jurnal.uns.ac.id/prosbi/article/download/21112/16398.

[44] N. S. Goedhart, N. Blignaut-van Westrhenen, C. Moser, and M. B. M. Zweekhorst, "The Flipped Classroom: Supporting A Diverse Group of Students in Their Learning," Learn. Environ. Res., vol. 22, no. 2, pp. 297-310, 2019, doi: 10.1007/s10984-019-09281-2.

[45] Ermayenti and Heryanto, "The Effect of Competence and Discipline of Work on Public Satisfaction in The Regional Office of The Ministry of Religion in West Sumatera Province with Quality of Service As An Intervening Variable," Arch. Bus. Res., vol. 7, no. 7, pp. 69-87, 2019. [Online]. Available: http://116.203.177.230/index.php/ABR/article/view/6638 
[46] R. Kurniawan, M. Haizam Mohd Saudi, and Z. Raphael Wijaya, "The Influence of Brand Equity and STP towards Pricing Strategy and the Impact on Decision Making," Int. J. Eng. Technol., vol. 7, no. 4.34, pp. 318-326, 2018, doi: 10.14419/ijet.v7i4.34.25304.

[47] R. Meng, et al., "The Chinese Version of The Perceived Stress Questionnaire: Development and Validation Amongst Medical Students and Workers," Health Qual. Life Outcomes, vol. 18, no. 1, pp. 1-17, 2020, doi: 10.1186/s12955-020-01307-1.

[48] P. J. Selby, J. A. Chapman, J. Etazadi-Amoli, D. Dalley, and N. F. Boyd, "The Development of A Method for Assessing the Quality of Life of Cancer Patients," Br. J. Cancer, vol. 50, no. 1, pp. 13-22, 1984, doi: 10.1038/bjc.1984.134.

[49] E. Almanasreh, R. Moles, and T. F. Chen, "Evaluation of Methods Used for Estimating Content Validity," Res. Soc. Adm. Pharm., vol. 15, no. 2, pp. 214-221, 2019, doi: 10.1016/j.sapharm.2018.03.066.

[50] U. Nurfillaili, M. Yusuf, and S. Anggereni, "Development of cognitive learning outcomes test instruments for physics subjects on the subject of business and energy of first semester second grade SMA Negeri Khusus Jeneponto (in Bahasa)," J. Pendidik. Fis., vol. 4, no. 2, pp. 83-87, 2016.

[51] C. K. Azzahri, D. Widjanarko, and I. M. Sudana, "Development of an Assessment Instrument for Jogja Paes Ageng Bridal Makeup Practices in the Javanese Bridal Makeup Course," J. Vocat. Career Educ., vol. 2, no. 1, pp. 22-27, 2017, doi: 10.15294/jvce.v2i1.10928.

[52] Y. Efendi and A. Widodo, "The validity test and reliability of the football schooting test instrument on the Persiwu FC Jatiyoso team player (in Bahasa)," J. Kesehat. Olahraga, vol. 7, no. 2, pp. 367-372, 2019.

[53] R. S. W. Gabriela V. Wales, and Silvya L. Mandey, "The Influence of Organizational Culture, Leadership Style, and Work Discipline on Employee Performance at Pt. State Savings Bank (Persero) Tbk. Manado Branch Office (in Bahasa)," J. EMBA J. Ris. Ekon. Manajemen, Bisnis dan Akunt., vol. 5, no. 3, pp. 4435-4444, 2017.

[54] B. S. Aji and M. E. Winarno, "Development of Knowledge Assessment Instruments for Physical Education and Health Subjects (PJOK) VIII Grade First Semester (in Bahasa)," J. Pendidik., vol. 1, no. 7, pp. 1449-1463, 2016.

[55] W. K. Adams and C. E. Wieman, "Development and validation of instruments to measure learning of expert-like thinking," Int. J. Sci. Educ., vol. 33, no. 9, pp. 1-24, 2010, doi: 10.1080/09500693.2010.512369.

[56] M. Khumaedi, "The Reliability of Education Research Instruments (in Bahasa)," Jurnal Pendidikan Teknik Mesin, vol. 12. pp. 25-30, 2012

[57] F. Yusup, "Test the Validity and Reliability of Quantitative Research Instruments (in Bahasa)," J. Tarb. J. Ilm. Kependidikan, vol. 7, no. 1, pp. 17-23, 2018, doi: 10.18592/tarbiyah.v7i1.2100.

[58] T. K. Ngang, S. Nair, and B. Prachak, "Developing Instruments to Measure Thinking Skills and Problem Solving Skills among Malaysian Primary School Pupils," Procedia - Soc. Behav. Sci., vol. 116, pp. 3760-3764, 2014, doi: 10.1016/j.sbspro.2014.01.837.

[59] A. C. de Souza, N. M. C. Alexandre, and E. de B. Guirardello, "Psychometric Properties in Instruments Evaluation of Reliability and Validity," Epidemiol. Serv. Saude, Brasília, vol. 26, no. 3, pp. 649-659, 2017, doi: $10.5123 / \mathrm{S} 1679-49742017000300022$.

[60] A. Suratno, "Developing Assessment Instruments in Competence Practice Engine Student in SMK Automotive Engineering Program (in Bahasa)," VANOS J. Mech. Eng. Educ., vol. 1, no. 1, pp. 1-11, 2016.

[61] F. W. Pinilih, R. Budiharti, and E. Y. Ekawati, "The Development of An Assessment Product Instrument on Science Learning for Junior High School Students," J. Pendidik. Fis., vol. 1, no. 2, 2013. [Online]. Available: https://jurnal.fkip.uns.ac.id/index.php/pfisika/article/viewFile/2798/1914. 